RESEARCH PAPER

\title{
Public health foundations and the tobacco industry: lessons from Minnesota
}

\author{
J K Ibrahim, T H Tsoukalas, S A Glantz
}

Tobacco Control 2004;13:228-236. doi: 10.1136/tc.2003.006866

See end of article for authors' affiliations

Correspondence to: Professor Stanton A Glantz, Box 1390, University of California, San Francisco, CA 94143-1390, USA. glantz@medicine.ucsf.edu

Received

24 November 2003

Accepted 12 March 2004
Objective: To investigate whether private foundations can be created in a way that will insulate them from attacks by the tobacco industry, using the Minnesota Partnership for Action Against Tobacco (MPAAT) as a case study.

Design: Information was collected from internal tobacco industry documents, court documents, newspapers, and interviews with health advocates and elected officials.

Results: The creation of MPAAT as an independent foundation did not insulate it from attacks by tobacco industry allies. During 2001-2002, MPAAT was repeatedly attacked by Attorney General Mike Hatch and major media, using standard tobacco industry rhetoric. This strategy of attack and demands for information were reminiscent of previous attacks on Minnesota's Plan for Nonsmoking and Health and the American Stop Smoking Intervention Study (ASSIST). MPAAT was ultimately forced to restructure its programme to abandon effective community norm change interventions around smoke-free policies and replace them with less effective individual cessation interventions. Neither MPAAT nor other health advocates mounted an effective public response to these attacks, instead relying on the insider strategy of responding in court.

Conclusion: It is not possible to avoid attacks by the tobacco industry or its political allies. Like programmes administered by government agencies, tobacco control foundations must be prepared for these attacks, including a proactive plan to educate the public about the principles of community based tobacco control. Public health advocates also need to be willing to take prompt action to defend these programmes and hold public officials who attack tobacco control programmes accountable for their actions.
$T^{1}$ he tobacco industry has historically used campaign contributions $^{1-4}$ and lobbying, often indirectly through front groups and third party allies, ${ }^{5-8}$ to influence the enactment and implementation of legislation, including the creation and financing of tobacco control programmes. The industry has succeeded in limiting the scope of these programmes $^{910}$ or eliminating them, often with claims of budget crises. ${ }^{811}$ The industry has harassed state and local tobacco control programmes through the use of massive requests under the Freedom of Information $\mathrm{Act}^{7}{ }^{12}$ (FOIA) as well as alleged misuse of public funds to engage in illegal lobbying. ${ }^{12} 13$

In an effort to insulate tobacco control programmes from the tobacco industry's political pressures, a Blue Ribbon commission of US public health experts, the 1997 National Advisory Committee on Tobacco Policy and Public Health, recommended creating private foundations to fund and implement tobacco control programmes. It recommended that these foundations:

"... be structured to assure such programs will be as free as possible from tobacco industry and political censorship or constraints, including the freedom to advocate the enactment of tobacco control policies, to expose tobacco industry wrongdoing and to challenge the failure of government entities to carry out the law, whether the funds are allocated to government agencies, such as state health departments, or to non-governmental organizations."

"One potential approach: a portion of available funds flowing into a trust administered, as in the Australian model, by a state-chartered, but independent Health
Foundation, governed by a board composed of the leaders of health and other nongovernment organizations who are not recipients of funding. ${ }^{\prime \prime 14}$

The committee's recommendations guided the creation of the Minnesota Partnership for Action Against Tobacco (MPAAT) in 1998, which did provide insulation from traditional political attacks through the legislative process or executive branch, but left it vulnerable to attacks by the attorney general, who has responsibility for oversight of private foundations in most states. ${ }^{12}$

Creation of a private foundation also does not shelter it from public relations attacks by the tobacco industry or its allies. Such attacks in Minnesota were successful in forcing MPAAT to refocus its purpose of reducing smoking by promoting clean indoor air and replacing it with the less cost effective intervention ${ }^{15}$ of providing direct cessation services. The attacks on MPAAT were similar to earlier industry inspired attacks of Minnesota's Plan on Nonsmoking and Health in the 1980s and the state's ASSIST (American Stop Smoking Intervention Study) programme in the 1990s. ${ }^{16}{ }^{17}$ The MPAAT case demonstrates that creation of a private foundation does not end the need for a proactive public defence, both from within the programme and from the public health community.

Abbreviations: ASSIST, American Stop Smoking Intervention Study; CID, civil investigative demand; FOIA, Freedom of Information Act; IBEW, International Brotherhood of Electrical Workers; MPAAT, Minnesota Partnership for Action Against Tobacco; MSA, Master Settlement Agreement; RAGA, Republican Attorneys General Association 


\section{METHODS}

Information on the attack on MPAAT was gathered as part of research detailing the history of tobacco control in Minnesota ${ }^{17}$ using news reports, state and federal documents, court documents, and interviews with health advocates and state officials. Interviews were conducted in compliance with protocol approved by the Committee on Human Subjects Research. Tobacco industry documents (available at legacy. library.ucsf.edu) were searched using the following terms: MPAAT, Minnesota Partnership for Action Against Tobacco, Minnesota trial and settlement; the resulting documents were used to locate other relevant documents using standard techniques. $^{18}$

\section{RESULTS}

\section{MPAAT's original plan}

MPAAT was created as part of Minnesota's legal settlement with the tobacco industry in 1998. The settlement allocated $\$ 102$ million to MPAAT's Cessation Account (paid by the tobacco industry in December 1998) and the remaining $\$ 100$ million would be paid in $\$ 10$ million annual payments for subsequent 10 years. ${ }^{19}$ The charge to the new foundation established in the settlement approved by the Ramsey County Court was very broad: the funds were to be used for such activities as the "directors of the foundation may determine will diminish the human and economic consequences of tobacco use" ${ }^{\prime \prime}{ }^{20}$

The settlement sought to create a board of directors with expertise and commitment to tobacco control. The 21 board members would be appointed as follows: one director-at large, two directors each appointed by the Speaker of the Minnesota House of Representatives, the Minnesota Senate Majority Leader, the governor, and the state attorney general, two directors who are employees or officials of city, county or local governmental bodies, eight directors from the public health community (including health advocates and the University of Minnesota), and two directors with special skills in community organising. ${ }^{19} 20$ While this structure for the board ensured leadership with strong commitment and expertise to carry out MPAAT's mission, it did create a situation in which MPAAT would be supporting organisations that had members on the MPAAT board. There are many precedents for this situation in science and health, such as voluntary health associations that support research at universities when faculty members are on the health agency board or members of National Institutes of Health scientific peer review groups that may review grants from colleagues at the same institution. MPAAT's board dealt with these potential conflicts of interest by adopting the long established conflict of interest guidelines used by the National Institutes of Health. ${ }^{21}$

MPAAT developed its tobacco control campaign ${ }^{20}$ to reduce tobacco use based on a careful review of existing tobacco control programmes, with particular attention to the recommendations of the National Advisory Committee on Tobacco Policy and Public Health. ${ }^{14}$ In addition, MPAAT's incorporating documents, which were approved by the court, stated that the board of directors would work to reinforce and strengthen the public infrastructure for tobacco control at the community and state level..$^{20}$ After a careful review of the evidence, MPAAT concluded that a programme concentrating on community norm change, particularly education about secondhand smoke and support for smoke-free policies, ${ }^{22}$ would be a more cost effective strategy to meet its mission of "diminish[ing] the human and economic consequences of tobacco use" than one-on-one smoking cessation. ${ }^{15}$

Like several states had done, ${ }^{10}$ MPAAT implemented its programme by funding a combination of mass media advertising and technical assistance to communities to develop policies to reduce exposure to secondhand smoke and create local tobacco control infrastructures, all of which were a major threat to the tobacco industry ${ }^{12}$ (table 1). Policy interventions, such as smoke-free workplaces, are particularly opposed by the tobacco industry because they substantially and quickly decrease cigarette consumption. ${ }^{22}$ The magnitude of the tobacco industry's efforts to prevent the passage of local clean indoor air policies corroborates the potential value of those policies. ${ }^{23}$

MPAAT also provided financial support for the coalition (Vote Yes! Yes! Yes! For Healthy Air Committee) supporting the first local smoke-free workplace and public place policy in Minnesota by assisting health advocates in Duluth in $2000 .^{24}$ Based on experiences in California, ${ }^{10}$ the successful passage and defence against industry efforts to repeal the Duluth ordinance would be the foundation upon which local clean indoor ordinances would rapidly spread throughout the state.

\section{The attack on MPAAT begins}

On 18 November 2001, David Phelps and Deborah CaufieldRyback, business reporters from the Minneapolis Star-Tribune, published an extensive front page article criticising MPAAT. ${ }^{25}$ This story, the first of 13 that would run through April 2002, alleged that MPAAT had ignored its charter by concentrating on community norm change, particularly promoting smokefree environments, ${ }^{24}$ rather than funding individual smoking prevention and cessation. The reporters, however, ignored MPAAT's incorporating documents which stated that the proposed plan is not a detailed roadmap to a solution of these problems. Rather, it is intended to establish the best possible structure to achieve the solutions, a structure marked by programme expertise and public accountability. ${ }^{26}$ The intent in creating MPAAT was that through consultation with experts in the field and a bi-annual report to the Legislature, the organisation would be accountable to the public and maintain an effective programme.

Phelps and Caufield-Rybak's initial attacks relied exclusively on sources with links to the tobacco industry, such as the conservative Cato Institute which receives funding from the tobacco industry. ${ }^{27-29}$ (The Star-Tribune did not report the tobacco ties for the sources they quoted to criticise MPAAT.) They did not present a balanced opportunity for health advocates to respond specifically to the accusations. ${ }^{3031}$ Rather than conducting current interviews, the information quoted from MPAAT board members was a broad commentary that MPAAT was doing the right thing and in several cases, quotes from past interviews or MPAAT board meetings were used.

Phelps and Caulfield-Ryback's stories also included accusations of misconduct in the evaluation and funding of grants $^{25}$ and assertions of conflicts of interest that led board members or their associated organisations to directly benefit from MPAAT grants.32 The event which sparked these accusations was the submission of a grant from the International Brotherhood of Electrical Workers (IBEW), aided by Philip Morris' contract lobbyist Chuck Westin, to MPAAT for the purpose of providing smoking cessation to IBEW members. ${ }^{30}$ MPAAT rejected the proposal because its incorporating document clearly states, "this corporation may not make any grant, contribution or contract, or render any other financial assistance, if the Board determines that the effect of the grant would be to reduce or substitute for benefits available from private insurance or other programmes", ${ }^{20}$ and the cessation programmes for its members was already covered by IBEW. ${ }^{30}$ Claims of conflicts of interest were also made by organisations with ties to the tobacco industry, including the Duluth Hospitality Association. ${ }^{33} 34$ 
Table 1 Programme allocations for MPAAT, 2000 and $2002^{84}$

\begin{tabular}{|c|c|c|c|}
\hline Recipient & Purpose (grant duration) & 2000 & 2002 \\
\hline \multicolumn{4}{|l|}{ Intervention } \\
\hline $\begin{array}{l}\text { Med/Ed Tob Smoke } \\
\text { Task Force }\end{array}$ & $\begin{array}{l}\text { To reduce exposure to secondhand smoke in restaurants, bars, businesses, } \\
\text { and schools in Marshall and Pennington counties ( } 2 \text { years) }\end{array}$ & $\$ 152806$ & \\
\hline $\begin{array}{l}\text { North Central } \\
\text { Service Coop }\end{array}$ & $\begin{array}{l}\text { To increase the number of smoke-free restaurants in Crow Wing, Todd, } \\
\text { and Wadena counties ( } 2 \text { years) }\end{array}$ & $\$ 200000$ & \\
\hline $\begin{array}{l}\text { Morrison County } \\
\text { Public Health }\end{array}$ & $\begin{array}{l}\text { To raise awareness and reduce exposure to secondhand smoke in Morrison } \\
\text { County (around public schools, entrances to health care facilities, } \\
\text { government buildings/grounds, and worksites) ( } 2 \text { years) }\end{array}$ & $\$ 120386$ & \\
\hline $\begin{array}{l}\text { American Cancer } \\
\text { Society (Midwest) }\end{array}$ & $\begin{array}{l}\text { To change policies to promote health by reducing exposure to } \\
\text { secondhand smoke in Hennepin and Kandiyohi counties ( } 2 \text { years) }\end{array}$ & $\$ 199530$ & \\
\hline American Lung & To build community readiness for public policy change to reduce & $\$ 369000$ & \\
\hline Assoc. of $M N$ & exposure to secondhand smoke in Greater Minnesota ( 2 years) & & \\
\hline $\begin{array}{l}\text { MN Smoke-Free } \\
\text { Coalition }\end{array}$ & $\begin{array}{l}\text { To create and implement a statewide grassroots plan to eliminate } \\
\text { exposure to second hand smoke ( } 2 \text { years) }\end{array}$ & $\$ 592050$ & \\
\hline $\begin{array}{l}\text { MN Smoke-Free } \\
\text { Coalition }\end{array}$ & $\begin{array}{l}\text { To implement a project to mitigate the influences of the tobacco } \\
\text { industry in Minnesota; this included a media campaign ( } 2 \text { years) }\end{array}$ & $\$ 201565$ & \\
\hline Chicanos Latinos & To establish an ethnic tobacco network representing the Chicano/ & $\$ 245000$ & \\
\hline Unidos E n Servicio & Latino community in Minnesota ( 3 years) & & \\
\hline Asian Bus \& Comm & To build an ethnic network to reduce tobacco use within the & $\$ 245000$ & \\
\hline Found & Southeast Asian community in Minnesota (3 years) & & \\
\hline $\begin{array}{l}\text { William Mitchell } \\
\text { College of Law }\end{array}$ & $\begin{array}{l}\text { To work with unions and workers to address tobacco } \\
\text { use in the workplace ( } 2 \text { years) }\end{array}$ & & $\$ 365000$ \\
\hline MN Nurses Assoc. & $\begin{array}{l}\text { To develop a statewide partnership with labour unions to } \\
\text { reduce exposure to secondhand smoke and promote cessation ( } 2 \text { years) }\end{array}$ & & $\$ 200000$ \\
\hline University of $\mathrm{MN}$ & $\begin{array}{l}\text { To develop, promote, and evaluate weekly Smoke-free Saturday } \\
\text { Night events in Minneapolis and St Paul, targeting youth ( } 2 \text { years) }\end{array}$ & & $\$ 298038$ \\
\hline Park Nicollet Institute & $\begin{array}{l}\text { To increase awareness of dangers of tobacco use and secondhand } \\
\text { smoke among Hispanic employees and employers ( } 2 \text { years) }\end{array}$ & & $\$ 250794$ \\
\hline University of $\mathrm{MN}$ & $\begin{array}{l}\text { To develop a statewide partnership to decrease tobacco use rates } \\
\text { and exposure to secondhand smoke by } 18-24 \text { year olds ( } 2 \text { years) }\end{array}$ & & $\$ 163812$ \\
\hline $\begin{array}{l}\text { Rainbow Health } \\
\text { Initiative }\end{array}$ & $\begin{array}{l}\text { To develop a partnership to reduce exposure to secondhand smoke } \\
\text { and promote cessation among the LGBT community ( } 2 \text { years) }\end{array}$ & & $\$ 164517$ \\
\hline Our Neighborhood & To reduce exposure to secondhand smoke in North Minneapolis & & $\$ 283419$ \\
\hline Council on Black & To establish an ethnic tobacco network representing the African & & $\$ 245000$ \\
\hline Minnesotans & American and African community in Minnesota ( 3 years) & & \\
\hline Research & & & \\
\hline $\begin{array}{l}\text { Hmong National } \\
\text { Organization }\end{array}$ & $\begin{array}{l}\text { To create a community-academic partnership to establish research } \\
\text { methods about tobacco use with Hmong youth ( } 18 \text { months) }\end{array}$ & $\$ 119319$ & \\
\hline University of $\mathrm{MN}$ & $\begin{array}{l}\text { To create a community-academic partnership with Indian Youth } \\
\text { Consortium to produce information about issues specifically related } \\
\text { to urban Indian youth tobacco use (18 months) }\end{array}$ & $\$ 123357$ & \\
\hline University of $\mathrm{MN}$ & $\begin{array}{l}\text { To lay the foundation for a clinical trial evaluating a novel approach to smoking } \\
\text { cessation through the use of sensory replacement among heavy smokers ( } 3 \text { years) }\end{array}$ & $\$ 494550$ & \\
\hline University of $\mathrm{MN}$ & $\begin{array}{l}\text { To research a model smoking cessation programme designed to have } \\
\text { health benefits for individuals with type } 2 \text { diabetes ( } 3 \text { years) }\end{array}$ & $\$ 449620$ & \\
\hline $\begin{array}{l}\text { Center for Energy } \\
\text { \& Environment }\end{array}$ & $\begin{array}{l}\text { To build a sound base of knowledge that will facilitate two types of interventions } \\
\text { to reduce renters' exposure to environmental tobacco smoke in their homes ( } 3 \text { years) }\end{array}$ & $\$ 470501$ & \\
\hline Mayo Clinic & $\begin{array}{l}\text { To research strategies that will help cigarette smokers who are undergoing } \\
\text { surgery manage and prolong abstinence in the pre- and postoperative period ( } 3 \text { years) }\end{array}$ & $\$ 477076$ & \\
\hline $\begin{array}{l}\text { HealthPartners } \\
\text { Research Foundation }\end{array}$ & $\begin{array}{l}\text { To determine if financial incentives increase the likelihood of } \\
\text { medical groups asking and assisting with quit attempts ( } 3 \text { years) }\end{array}$ & & $\$ 449992$ \\
\hline University of MN & $\begin{array}{l}\text { To assess knowledge, attitudes, and believes about tobacco use within } \\
\text { the LG BT community in the Twin Cities (18 months) }\end{array}$ & & $\$ 206451$ \\
\hline University of $\mathrm{MN}$ & $\begin{array}{l}\text { To investigate the policy of outdoor smoking restrictions in park/recreation } \\
\text { locations for changing tobacco use norms ( } 18 \text { months) }\end{array}$ & & $\$ 212126$ \\
\hline Park Nicollet Institute & $\begin{array}{l}\text { To solicit opinions of primary care physicians, specialists, and nurses to } \\
\text { determine ways to increase cessation counseling ( } 8 \text { months) }\end{array}$ & & $\$ 91277$ \\
\hline University of $\mathrm{MN}$ & $\begin{array}{l}\text { To improve upon the reach and effectiveness of existing cessation programmes by developing } \\
\text { a web based expert system to promote tobacco non-use among college students ( } 3 \text { years) }\end{array}$ & & $\$ 477927$ \\
\hline University of St Thomas & $\begin{array}{l}\text { To expand the understanding of factors that cause young adults ( } 18-24 \text { years old) to start or } \\
\text { stop smoking and/or expose themselves to secondhand smoke ( } 3 \text { years) }\end{array}$ & & $\$ 375162$ \\
\hline $\begin{array}{l}\text { Indigenous Peoples } \\
\text { Task Force }\end{array}$ & $\begin{array}{l}\text { To assess the motivating factors to smoke and the use patterns for American Indian women } \\
\text { who smoke during pregnancy, to build community readiness and develop recommendations } \\
\text { for intervention strategies ( } 2 \text { years) }\end{array}$ & & $\$ 159175$ \\
\hline
\end{tabular}

There was some validity to these accusations of conflict of interest, since some MPAAT Board and Advisory Committee members were directly receiving a benefit from the grants. There were six grants funded by MPAAT where a member of the MPAAT Research Advisory Committee was receiving a portion of his/her salary from that grant. ${ }^{35}$

These difficulties led others not allied with the tobacco industry to express concern; Marc Asch, President of Common Cause Minnesota observed:
There's no question [MPAAT] has a conflict... They give the money to the people who are represented on the Board... The treasurer of MPAAT resigned from the Board because of his concerns over conflicts of interest... the attack came because MPAAT was perceived by many people as having conflicts. ${ }^{36}$ [emphasis added]

After several months of public criticism over the conflict of interest issue, two MPAAT board members (Sandra 
Gardebring and Coral Houle) resigned on 20 March 2002. ${ }^{37}$ Gardebring, vice president for government relations at the University of Minnesota, one of the attorney general's appointees, was employed by one of the agencies to which the attorney general would propose shifting MPAAT's resources (discussed below).

The Star Tribune ignored a survey conducted by MPAAT on Minnesotans' knowledge, attitude, and behaviours regarding secondhand smoke which showed that approximately $90 \%$ of the population agreed that secondhand smoke was harmful, including $75 \%$ of all smokers in the state. ${ }^{38}$ The newspaper also repeated claims that MPAAT's support of smoke-free policies was dividing communities, based on claims by segments of the hospitality industry who were allied with the tobacco industry in fighting the Duluth ordinance. ${ }^{2433} 34$ The main opponent of the Duluth ordinance was not a well established organisation; the Duluth Hospitality Association was formed in the spring of 2000 for the purpose of opposing the ordinance. ${ }^{24}$ The tobacco industry's efforts to create new organisations and avoid public awareness of its opposition is a testament to the effectiveness of policy change such as implementing clean indoor air ordinances, ${ }^{23}$ and suggests that the opposition was rooted with the tobacco industry and not from within the community.

To avoid inflaming the story, MPAAT chose not to mount a major public response to the original Star-Tribune article. Rather, it responded with an opinion editorial by MPAAT Chair Richard Hurt, pointing out that the settlement that created MPAAT required consultation with other public health experts, including the Centers for Disease Control and Prevention, and other states and that these experts indicated that reducing the places where people may smoke protects everyone from secondhand smoke and helps smokers quit and remain tobacco-free. ${ }^{39}$ Hurt addressed the conflict of interest issue by noting that MPAAT had adopted the National Institutes for Health's conflict of interest procedures for evaluating and awarding grants. ${ }^{39}$ The StarTribune ran Hurt's article on a Saturday (November 25), the day with the lowest readership.

\section{The attorney general's involvement}

Attorney General Mike Hatch (D) was critical of MPAAT from its beginning. Rather than accepting MPAAT's justification for its strategies of reducing tobacco use as the Ramsey Court had when it accepted the incorporating articles, ${ }^{20}$ Hatch stated in the Star Tribune's first article, "They [MPAAT] have become so pure in ideology that they are arrogant, and they have forgotten their mission. Try to get people to stop smoking; don't force people." ${ }^{25}$ Hatch had both indirect and direct political and financial ties with the tobacco industry. He reimbursed Ron Jerich, an important tobacco lobbyist in Minnesota, for fundraising for his political campaign, ${ }^{40}$ accepted \$800 from Philip Morris' and RJ Reynolds' lobbyists in 1994 for his gubernatorial race, and $\$ 850$ from lobbyists representing the Minnesota Wholesale Marketers' Association and the Tobacco Institute during his campaign for attorney general in 1998. ${ }^{41}{ }^{42}$ While not large amounts of money in some states, these were significant amounts for Minnesota. ${ }^{17}$ Hatch's criticism of MPAAT was particularly significant, because only the attorney general had standing to challenge MPAAT's charter and actions in court. ${ }^{43}$

In January 2002, Hatch filed a motion in Ramsey County District Court, which was responsible for monitoring implementation of the Minnesota settlement, including MPAAT, to review MPAAT's activities. ${ }^{44} \mathrm{He}$ also asked MPAAT to voluntarily stop supporting local advocacy of smoke-free ordinances and limit its activities to helping individual people quit smoking. ${ }^{45}$ Again, neither MPAAT, its grant recipients, nor other health advocates came forward to publicly support the mission and work of MPAAT by citing the purpose set forth in the Minnesota settlement and the incorporating documents, which gave MPAAT room to determine the most effective way to reduce tobacco use through a thorough review of evidence based literature and expert opinion. ${ }^{20}{ }^{46}$

Attorney general Hatch also began issuing civil investigative demand (CID) requests to MPAAT grantees across the state. ${ }^{47}$ MPAAT grantees did not know that CIDs were a formal request for information but did not carry the legal standing of a subpoena, so they halted their smoke-free campaigns to provide the requested information. In addition to hindering progress, one grantee spent as much as \$20 000 in legal fees to respond to Hatch's request. ${ }^{47}$ MPAAT chair Hurt said in an interview with one of the authors on 16 August 2002, "He [Hatch] was asking for records and grants, financial records, anything ... he really wasn't asking to find information, he was ... just simply harass[ing]. As far as we know, those CIDs have never been reported, they were not part of the Court proceedings on the $17^{\text {th }}$ of May." ${ }^{\prime 47}$

On 19 April 2002, Hatch filed a motion with the court seeking to dissolve MPAAT and move its funds to the Minnesota Department of Health and the University of Minnesota. ${ }^{48}$ This action would bring the tobacco control programme under the control of the legislature and governor, the precise situation that MPAAT was designed to avoid. On 1 May Hatch further proposed replacing the MPAAT board with a five person committee, two of whom were former governors Arne Carlson (Ind) and Wendell Anderson (DFL). ${ }^{40}$ Carlson had accepted $\$ 5000$ in campaign contributions from the tobacco industry between 1989 and $1994,{ }^{17}$ used three of the tobacco industry's top lobbyists in Minnesota for his re-election campaign, ${ }^{51}$ and maintained a pro-tobacco position on legislation. ${ }^{17}{ }^{52}$ In addition, while governor, he, along with Wisconsin Governor Tommy Thompson (R) and their wives, took an extended vacation to Australia, courtesy of Philip Morris. ${ }^{53}$ Anderson's former chief of staff, Tom Kelm, was the chief tobacco industry contract lobbyist in Minnesota. ${ }^{54}$

By the time Judge Michael Fetsch considered the matter in May 2002, there had been 26 stories in the Star-Tribune, reporting the accusations of conflict of interest within the MPAAT board and misuse of public funds. Meanwhile, MPAAT and the health advocates had remained silent. It was not until May 2003 that MPAAT publicly responded to attacks from the attorney general and the Star-Tribune.$^{55}$ On 1 May 2003, MPAAT made a press release in response to the Tribune's claims that MPAAT's support of clean indoor air ordinances was dividing communities. ${ }^{37}$ The MPAAT press release quoted Duluth City Council member Greg Gilbert saying, "no single issue has been more actively discussed by a larger percentage of the Duluth population than the smoking ordinance and the harmful effects of smoking." ${ }^{155}$ A high turnout of $61 \%$ of eligible residents came out to vote for the off-year city election to uphold the Duluth ordinance following a forced referendum by opponents. ${ }^{55}$

It was also the beginning of May when the Washington DC based Campaign for Tobacco Free Kids, together with the Minnesota chapters of the American Cancer Society and the American Heart Association, began a radio advertising campaign, asserting that Big Tobacco and its allies wanted to shut MPAAT down. ${ }^{56}$ The Pioneer Press reported on 8 May 2002 that the American Cancer Society supported MPAAT's work. However, Gary Streit, vice chair of the ACS board of directors, went on to add that MPAAT should reduce the size of its board, implement better conflict-of-interest efforts to prevent money from going to groups linked to board members, and have an independent panel award all grants. ${ }^{57}$ No one criticised Attorney General Hatch's attacks on MPAAT. 
On 17 May, the attorney general's representative argued that MPAAT's \$202 million endowment should be removed from its jurisdiction ${ }^{58}$ because funding of local ordinance campaigns was political rather than scientific. ${ }^{59}$ MPAAT's $^{\prime}$ lawyer argued that MPAAT's activities were driven by evidence based research guided by the CDC and were grounded in the science of tobacco control and used effectively for that purpose..$^{58}$ Health advocates from across the USA submitted amicus briefs in defence of MPAAT's work and effectiveness. A brief from the Tobacco Control Resource Center in Massachusetts ${ }^{60}$ cited the American Journal of Public Health stating, "Strong clean indoor air ordinances have been associated with reductions in secondhand smoke exposure and decreased cigarette consumption among both adults and youths ${ }^{61}$ and an internal tobacco industry document admitting smokers facing [clean indoor air ordinances] consume $11-15 \%$ less than average and quit at a rate that is $84 \%$ higher than average." ${ }^{\prime 62}$

On 26 June 2002, Judge Fetsch denied Hatch's motion to appoint a new administrator to oversee MPAAT's \$202 million endowment and recognised the significance of MPAAT's independent status and its environmental approach to smoking cessation. ${ }^{63}$ At the same time, however, he ordered MPAAT to provide the court with a plan to deal with apparent conflicts of interest among its board of directors, its staff, and its grantees. ${ }^{63}$ In addition, the judge ordered that MPAAT shall not make any further grants except those existing grants which are designed to assist individual tobacco users ${ }^{64}$ until it provided an equal amount of funding for individual cessation programmes and environmentally based programmes ${ }^{65}$ (that is, local smoke free ordinance campaigns).

At the time of the court order, in 2002, MPAAT was in the process of awarding new grants. As a result, the controversy generated by the news media succeeded in essentially stopping the capacity for local environmental change. This was a clear victory for the tobacco industry who acknowledged the significant threat posed by environmental approaches to reducing tobacco use during. ${ }^{12}$ The tobacco industry had a longstanding strategy of directing tobacco control efforts away from environmental change to efforts directed at individual smokers. For example, a 1991 letter among RJ Reynolds Tobacco executives regarding how to deal with ASSIST recommended that RJ Reynolds should make programmes directed at pregnant women and youth a priority and secondary priorities may include smoking cessation programmes for people who have decided to quit. ${ }^{66}$

On 11 September 2002, MPAAT submitted a proposal to Judge Fetsch to redefine its board of directors and expand its individual cessation programme. ${ }^{67}$ MPAAT abandoned the National Institutes of Health conflict of interest guidelines and adopted a stricter policy that board members could not have received MPAAT funding within a year before serving and their organisations could not receive MPAAT funding within one year following their board membership. ${ }^{67}$ The new structure was composed of eight members nominated by the Governor, the attorney general, the Speaker of the House, and the Senate Majority Leader (two appointees each) and 11 at-large members. According to MPAAT's proposal to the Court,

\footnotetext{
"The new MPAAT Board will be drawn broadly from the general population. This reflects a change from the requirements of the original Court Order that specific types of organizations be represented on MPAAT's Board - a requirement that created the potential for conflicts of interest... a broader class of at-large members will ensure
}

a Board that retains expertise in diverse areas and is able to aggressively execute its fiduciary responsibilities. ${ }^{67}$

MPAAT's new grants in 2002 focused much less on community norm changes and much more on individual cessation services, ${ }^{67}$ including an internet counselling website, expansion of its existing telephone helpline, and distribution of nicotine patches and nicotine gum to smokers who are undergoing counselling but did not have health insurance coverage for such services. ${ }^{67}$ By 30 June 2003 MPAAT had more than satisfied the court ruling and awarded approximately $\$ 6.4$ million (61\%) of its grant funds for the purpose of cessation programmes and approximately $\$ 4$ million $(39 \%)$ of its grant funds for the purpose of programmes addressing secondhand smoke over the life of the foundation (table 1 ). ${ }^{68}$

In February 2003, Judge Fetsch refused another effort by the attorney general to remove MPAAT's funding. ${ }^{69}$ In addition, the judge approved MPAAT's individual cessation and new governance plans ${ }^{71}$ stating, "It is not the Court's purpose or mission to strictly bind the activities of MPAAT in its day to day operations or to architect in detail how MPAAT is to conduct its research or its anti-smoking campaigns. MPAAT must have operational freedom. With that freedom, however, comes the responsibility to scrutinize all of the uses to which the allocated monies are put and to insure that the dual ends of research and cessation are properly served. ${ }^{\prime 71}$

\section{DISCUSSION}

While the players were different from tobacco industry attacks on tobacco control programmes managed by state agencies, ${ }^{7813}$ the attack on MPAAT resembled earlier attacks in the state including the Minnesota Plan for Nonsmoking and Health and ASSIST (table 2). The effort against MPAAT began with news stories attacking the priorities, legality, and ethics of MPAAT's tobacco control campaign. This questioning was followed with broad requests for documents from organisations working to advocate for smoke-free policies, followed by a legal attack. The difference from earlier cases, however, was that the attacks were led by a major newspaper and the attorney general rather than tobacco industry inspired smokers' rights groups. While the attorney general failed to shut down MPAAT and shift its assets to state agencies that would be subject to more direct political control (and, so, more susceptible to industry pressure), he did succeed in forcing MPAAT to abandon its efforts to create smoke-free environments and replace them with individual smoking cessation, which posed much less of a threat to the tobacco industry.

\section{Attacks on credibility}

In the Star-Tribune's attack on MPAAT, Phelps and CaufieldRyback focused the debate on accountability and claimed that MPAAT was not following its mission as established in the original tobacco settlement. A search of Lexis-Nexus reveals that a total of 38 articles were written on the topic of MPAAT between November 2001 and May 2003, primarily by the Minneapolis Star Tribune (one story each covered by the St Paul Pioneer Press and the Associated Press in St Paul). The Tribune's coverage did not provide equal attention to the effectiveness and quality of MPAAT's plan as assessed by public health authorities. It is a common public relations strategy to ignore negative press, but because of the frequency and intensity of press coverage, MPAAT's silence appeared to be an admission of guilt, which was reinforced by the silence of members of the public health community, until the radio campaign in May 2002. ${ }^{65}$ MPAAT director Richard Hurt acknowledged MPAAT's insider strategy ${ }^{4}{ }^{11}$ by saying, "We're anxious to get in front of the judge to tell the 
Table 2 Tobacco industry strategies to attacks tobacco control efforts in Minnesota (MN)

\begin{tabular}{|c|c|c|c|}
\hline Strategy & $\begin{array}{l}\text { MN plan for non-smoking and } \\
\text { health-public education campaign }\end{array}$ & ASSIST & MPAAT \\
\hline Diversion of issues & $\begin{array}{l}\text { Shift the arguments from health to } \\
\text { economics and government interventions } \\
\text { and claim that the interventions are } \\
\text { not rooted in scientific evidence }\end{array}$ & $\begin{array}{l}\text { Use FOIA to obtain ASSIST grantee } \\
\text { documents to search for use of } \\
\text { funds not within guidelines of } \\
\text { ASSIST }\end{array}$ & $\begin{array}{l}\text { Claim that MPAAT is not being held } \\
\text { accountable and has abandoned its } \\
\text { guiding principles }\end{array}$ \\
\hline Use of third party allies & $\begin{array}{l}\text { MN Grocers Associations, Teamsters } \\
\text { Union, AFSCME, community groups, } \\
\text { and tobacco wholesalers and retailers }\end{array}$ & $\begin{array}{l}\text { MN Grocers Association and } \\
\text { tobacco wholesalers and retailers }\end{array}$ & $\begin{array}{l}\text { Minneapolis Star Tribune, MN AFL-CIO, } \\
\text { MN Hospitality Association, local } \\
\text { chambers of commerce, MN Taxpayers } \\
\text { League }\end{array}$ \\
\hline Misuse of funds & & $\begin{array}{l}\text { Claim bias and conflict of interest } \\
\text { in the review of ASSIST } \\
\text { grant applicants }\end{array}$ & $\begin{array}{l}\text { Claim that MPAAT was using funds for } \\
\text { enacting local ordinances rather than } \\
\text { helping people quit smoking }\end{array}$ \\
\hline Political expenditures & $\begin{array}{l}\text { Campaign contributions to key officials and } \\
\text { use of lobbyists to stimulate procedural fights }\end{array}$ & $\begin{array}{l}\text { Contributions to third party allies, } \\
\text { including the MN Grocers } \\
\text { Association }\end{array}$ & $\begin{array}{l}\text { Campaign contributions to Attorney } \\
\text { General Michael Hatch }\end{array}$ \\
\hline
\end{tabular}

full story" ${ }^{72}$ In the meantime, its standing with the public deteriorated.

Health advocates and MPAAT grantees should have come forward and exposed the tobacco ties of the attorney general, holding him accountable for his actions. ${ }^{8}$ While directly confronting Hatch may have been risky, given the political power of the position of attorney general, there is evidence that by revealing the tobacco ties of top level elected officials, tobacco control progress can be protected. For example, this strategy helped save the California Tobacco Control Program in the mid 1990s, ${ }^{10}$ and in Connecticut in 2002 when health advocates revealed the ties between the State Speaker of the House and Phillip Morris ${ }^{73}$ as the first step towards the passage of a statewide Clean Indoor Air Act that made restaurants and bars smoke-free. ${ }^{74}$ In addition, the advocates should have stressed the language of MPAAT's courtapproved incorporating documents, ${ }^{20}$ since these documents were, in fact, guiding MPAAT's work.

The silence of tobacco control advocates in Minnesota was surprising, given that the attack on MPAAT was so similar to two earlier episodes in Minnesota when the tobacco industry succeeded in derailing those tobacco control programmes. In the early 1990s, the industry used claims of a budget crisis to end the first state tobacco control programme, ${ }^{8}$ the Minnesota Plan for Nonsmoking and Health, followed by attacks on Minnesota's ASSIST programme which was part of a nationwide tobacco control experiment led by the National Cancer Institute. ${ }^{12}{ }^{75}$ In the case of ASSIST, the attack was largely centred on allegations of bias in reviewing a grant proposal from the Minnesota Grocers Association to train tobacco grocery retailers to identify minors attempting to purchase tobacco products. ${ }^{17}$ The tobacco industry made contributions to the Minnesota Grocers' Association of \$31 000 between 1989 and $1999^{76-78}$ and $\$ 45000$ to the Minnesota Wholesale Marketers Association in $1996 .{ }^{79}$ Five years later, a grant proposal submitted by the International Brotherhood of Electrical Workers (IBEW) with assistance from Philip Morris lobbyist Chuck Westin was the spark to ignite the attacks on MPAAT. ${ }^{30}$

Minnesota's Association for Nonsmokers' Rights' president Jeanne Weigum and MPAAT board member (before the restructuring) commented on the similarities between the tobacco industry attacks on tobacco control in Minnesota. "The parallels are just astounding. It's like, we can't learn from their playbook and they use the same playbook."16 Weigum goes on to say that the attacks were intended:

\footnotetext{
"...to stop the local ordinance activity, which you will now
} see they were successful at. Now there is an ASSIST document that starts with the entire ASSIST [program] has been shut down, no grants have been [approved], no grants will be funded, and grants where contracts had been signed were put on hold, and I read that paragraph again after some time and it read exactly about what happened with MPAAT, the parallels are so striking that I don't know how one could miss them. ${ }^{\prime \prime 16}$

Despite this acknowledgment from health advocates, there was no public defence from any of MPAAT's members, grantees or supporters, leaving the foundation crippled in the same way that the ASSIST programme had been crippled.

As elsewhere, ${ }^{72}$ the tobacco industry's attacks on the ASSIST programme in Minnesota relied on Freedom of Information Act requests by the Minnesota Wholesale Marketers' Association and the Minnesota Grocers Association $^{80} 81$ to harass ASSIST contractors under the guise of extracting information followed by allegations of misuse of funds and illegal lobbying. ${ }^{13}$ While a minor $\$ 40$ violation was found, it was estimated that over 300 hours was spent by state officials responding to the request. ${ }^{82}$ Attorney General Hatch's attacks on MPAAT relied on civil investigative demands to essentially halt the progress of local clean indoor air ordinance campaigns in Minnesota and cost one grantee alone up to $\$ 20000 .^{47}$

MPAAT could have advised its grantees at the time that these were not subpoenas and that they should continue with current activities; however, no such action was taken. Despite this broad request for documents from the attorney general, none of the resulting material was used in any of his legal proceedings against MPAAT. ${ }^{47}$

\section{Claims of misuse of funds and conflict of interest}

The claim that tobacco control efforts were misusing allocated resources is another common tobacco industry attack strategy. In Minnesota, MPAAT was accused of using funds for pursuing local tobacco control ordinances rather than helping smokers to quit, without acknowledging that MPAAT adopted this strategy after a careful review of experience elsewhere which demonstrated that a population based, not individual based, approach was the more cost effective way to help smokers quit. ${ }^{83}$ A review of the literature on the effectiveness of tobacco control programmes states that promoting local clean indoor air policies should be a specific focus for tobacco control. ${ }^{23}$ However, opposition to such an approach was necessary for the tobacco industry who has acknowledged that policy change at the local level is a major threat to its existence. ${ }^{12}$ President of Common Cause Minnesota, Marc Asch, observed, "Hatch has been able to muddy these two issues [conflicts of interest and appropriate 
use of funds]...to be able to kind of roll it all together to undermine their credibility." ${ }^{\prime \prime 6}$

In recommending the creation of foundations like MPAAT, the 1997 National Advisory Committee on Tobacco Policy and Public Health was conscious of the issue of conflict of interest, so it recommended that the board be composed of the leaders of health and other non-government organisations who are not recipients of funding. ${ }^{14}$ MPAAT dealt with this potential conflict by adopting the National Institute of Health's conflict of interest procedures, ${ }^{21}$ which are widely accepted within the biomedical research and public health communities. MPAAT, however, appears to have not applied the NIH model with adequate vigour, since in several cases people funded directly by MPAAT (as opposed to organisations funded by MPAAT) were closely involved in the grant selection process

\section{A new tobacco ally}

During the 1990s, when a growing number of state attorneys general were joining law suits against the tobacco industry, these elected officials seemed committed to supporting tobacco control. This was certainly the case in Minnesota, where then attorney general, Hubert Humphrey III, had been a leader in this litigation. However, in 2003, the tobacco industry began to find a new ally in some attorneys general. In Spring 2003, 37 attorneys general (including many who had sued the tobacco industry) filed a Brief of Amici Curiae in support of Philip Morris, who was attempting to avoid having to post a $\$ 12$ billion appeal bond after it lost a class action lawsuit claiming that its marketing of light and mild cigarettes defrauded the public. ${ }^{85}$

The attorneys general accepted Philip Morris' claim that posting this bond might jeopardise Philip Morris' ability to make payments to the states required by the Master Settlement Agreement (MSA) that settled state tobacco litigation and argued that the states' financial interests justified giving Philip Morris special treatment with regard to posting the appeal bond. The attorneys general hold a great deal of power over foundations such as MPAAT for two reasons. First, in most states, the attorney general exercises authority over non-profit foundations, including the ability to investigate them to ensure that they are acting consistent with their charters. Second, any attorneys general who were party to the MSA or individual settlements with the tobacco companies, have authority over the resulting foundations to guarantee that the terms of the settlement are followed.

The tobacco industry has recognised the importance of the attorneys general in the post-MSA environment by increasing campaign contributions to them through organisations such as the Republican Attorneys General Association (RAGA). RAGA was conceived by Alabama Attorney General Bill Pryor (R) in 1999, as a means of defending against the alliances that some attorneys general had formed with private lawyers to sue the tobacco industry. ${ }^{86}$ Attorney General Pryor warned:

\section{"...that the lawsuits filed by my fellow state attorney general against the tobacco industry threatened the entire business community... the legal landscape has deterio- rated to the point that, with municipalities and states suing the firearms and pain industries and the federal govern- ment suing the tobacco industry, there are a growing number of novel government suits against the entire industries. No industry is safe. ${ }^{86}$}

\section{Lessons learned}

There are three important lessons that can be drawn from MPAAT's experience. First, it is not possible to design an

\section{What this paper adds}

Previous research examining attacks on government run tobacco control programmes has provided documentation of the standard rhetoric and strategies used by the tobacco industry, including undermining the science of a programme, diversion of issues so as to create confusion, use of third party allies, and the exercise of political power both through lobbying and political expenditures.

This paper shows that simply creating a private public health foundation, previously believed to be insulated from the political influence of the tobacco industry, did not prevent similar attacks. The Minnesota Partnership for Action Against Tobacco (MPAAT) was created as a private foundation through settlement of litigation against the tobacco industry with provisions to prevent attacks from the legislature; however this did not prevent attacks from other opponents, such as the attorney general. The fact that MPAAT did not act proactively and assertively to respond to and diffuse the public criticism contributed to its problems. As a part of defending a programme, tobacco control advocates must be willing to defend the position that policy interventions are a reasonable means of working to reduce tobacco use and exposure to secondhand smoke.

organisation that is immune from attack by the tobacco industry or its allies. By creating a private tobacco control foundation, the nature and channel of attack by the tobacco industry is changed, but not ended. Hence, if the administration of MPAAT's funds had been shifted to the Minnesota Department of Health and the University of Minnesota, as requested by Attorney General Hatch, the programme would have been vulnerable to attack from the legislature and the governor and not just the attorney general.

Second, health advocates must be prepared, proactive, and public. They must be prepared for attacks by the tobacco industry ${ }^{87}$ under the guise of third party allies or elected officials and respond quickly, ${ }^{9}$ as well as to educate the public about the programme's significance and effectiveness. ${ }^{87}$ MPAAT experienced a series of attacks between November 2001 and January 2003 without mounting an affirmative public defence, despite the fact that it was implementing a well conceived, evidence based programme designed to implement its assigned mission. While the Ramsey Court did prevent MPAAT's dissolution, MPAAT was forced to restructure its activities such that cessation became the overwhelming focus of the programme, largely leaving more cost effective clean indoor air activities behind. MPAAT funding of grants to reduce exposure to secondhand smoke declined from approximately \$2.1 million in 2000 to approximately $\$ 749000$ in 2002 (table 1). ${ }^{84}$ This restructuring was a clear victory for the tobacco industry which acknowledge environmental changes as a major threat and preferred that tobacco control advocates pursue less effective strategies, such as individual cessation. ${ }^{66}$

Finally, public health, by its very nature, involves pursuing public policy changes. ${ }^{13}$ Public policy is perhaps the primary means, along with education, through which public health agencies achieve their goals of protecting public health. ${ }^{88}$ The tobacco industry recognises this and works to create controversy around this topic as a means to prevent tobacco control organisations from making changes to public policy. ${ }^{13}$ Health advocates must recognise the strategies of the tobacco industry and challenge all opposition to tobacco control approaches that have been proven to be effective. ${ }^{87}$

One good example of how to handle attacks from the tobacco industry was recently seen from the American Legacy 
Foundation. In January 2002, Legacy was informed by Lorillard Tobacco that it would be filing suit against the Foundation on the basis that the truth ${ }^{\mathrm{sm}}$ antismoking advertising campaign sponsored by Legacy violated the vilification clause, ${ }^{89} 90$ which stated funds shall not be used for any personal attack on, or vilification of, any person (whether by name or business affiliation), company, or governmental agency, whether individually or collectively. ${ }^{91}$ Rather than waiting for Lorillard to file a case in a tobacco friendly court (such as in North Carolina), Legacy preemptively filed a motion for summary judgement to have Lorillard's case dismissed in Delaware, where Legacy is incorporated. While the court denied Legacy's motion for summary judgement, it did accept jurisdiction, preventing the case from being pursued in a North Carolina court. ${ }^{92} 93$ Unlike MPAAT, the court proceedings that followed have not halted Legacy's activities. Tobacco control programmes, whether foundation or state run programme, must learn from these experiences to prevent further success for the tobacco industry.

\section{Authors' affiliations}

J K Ibrahim, T H Tsoukalas, S A Glantz, Center for Tobacco Control Research and Education, University of California, San Francisco, San Francisco, California, USA

\section{REFERENCES}

1 Glantz SA, Begay ME. Tobacco industry campaign contributions are affecting tobacco control policymaking in california. JAMA 1994;272:1176-82.

2 Moore S, Wolfe SM, Lindes D, et al. Epidemiology of failed tobacco control legislation. JAMA 1994;272:1171-5

3 Monardi F, Glantz SA. Are tobacco industry campaign contributions influencing state legislative behavior? Am J Public Health 1998;88:918-23.

4 Givel MS, Glantz SA. Tobacco lobby political influence on US state legislatures in the 1990s. Tobacco Control 2001;10:124-34.

5 Dearlove JV, Bialous SA, Glantz SA. Tobacco industry manipulation of the hospitality industry to maintain smoking in public places. Tobacco Control 2002; 11:94-104.

6 Dearlove JV, Glantz SA. Boards of health as venues for clean indoor air policy making. Am J Public Health 2002;92:257-65.

7 Aguinaga S, Glantz SA. The use of public records acts to interfere with tobacco control. Tobacco Control 1995;4:222-30.

8 Tsoukalas TH, Glantz SA. Development and destruction of the first state funded anti-smoking campaign in the USA. Tobacco Control 2003; 12:214-20.

9 Balbach E, Glantz S. Tobacco control advocates must demand high-quality media campaigns: the California experience. Tobacco Control 1998;7:397-408.

10 Glantz SA, Balbach ED. Tobacco war: inside the California battles. Berkeley University of California Press, 2000

11 Givel M, Glantz S. Failure to defend a successful state tobacco control program: policy lessons from Florida. Am J Public Health 2000;90:762-7.

12 White J, Bero L. Public health under attack: the American stop smoking intervention study (Assist) and the tobacco industry. Am J Public Health 2003;94:240-50

13 Bialous SA, Fox BJ, Glantz SA. Tobacco industry allegations of "illegal lobbying" and state tobacco control. Am J Public Health 2001;91:62-7.

14 The Advisory Committee on Tobacco Policy and Public Health. Final Report of the Advisory Committee on Tobacco Policy and Public Health; 1997 July.

15 West R. Banning smoking in the workplace. BMJ 2002;325:174-5.

16 Weigum J. Interview with Theodore H. Tsoukalas. In, 2000.

17 Tsoukalas T, Ibrahim J, Glantz S. Shiffing tides: Minnesota tobacco politics. San Francisco, CA: Center for Tobacco Control Research and Education, Institute for Health Policy Studies, School of Medicine, University of California San Francisco, March 2003.

18 Malone RE, Balbach ED. Tobacco industry documents: treasure trove or quagmire? Tobacco Control 2000;9:334-8.

19 The State of Minnesota, by Hubert H. Humphrey III, It's Attorney General, and Blue Cross and Blue Shield of Minnesota, Plantiffs, Vs. Philip Morris Incorporated, R.J. Reynolds Tobacco Company, Brown \& Williamson Tobacco Corporation, B.A.T. Industries P.L.C., British-American Tobacco Company Limited, Bat (U.K. \& Export) Limited, Lorillard Tobacco Company, the American Tobacco Company, Liggett Group, Inc., the Council for Tobacco Research - U.S.A., Inc., and the Tobacco Institute, Inc., Defendents. In: State of Minnesota District Court, County of Ramsey, Second Judicial District, 1994.

20 Signed by Secretary of State Joan Anderson Grow. Certificate and Articles of Incorporation for the Minnesota Partnership for Action against Tobacco, Corporate Charter No. 18-229; 1998 Sept. 21.

21 National Institutes of Health Office of Extramural Research. NIH Grants Policy Statement. In: National Institutes of Health, 1998.
22 Fichtenberg CM, Glantz SA. Effect of smoke-free workplaces on smoking behaviour: systematic review. BMJ 2002;325:188-94.

23 Siegel $\boldsymbol{M}$. The effectiveness of state-level tobacco control interventions: a review of program implementation and behavioral outcomes. Annu Rev Public Health 2002;23:45-71.

24 Tsoukalas T, Glantz SA. The Duluth Clean Indoor Air Ordinance: problems and success in fighting the tobacco industry at the local level in the $21 \mathrm{st}$ century. Am J Public Health 2003;93:1214-21.

25 Phelps D, Caulfield-Rybak D. Spending the tobacco money: is this what the court had in mind? Minneapolis Star-Tribune; 2001.

26 Minnesota Partnership for Action Against Tobacco. Report to the Ramsey County District Court and the Minnesota Legislature, January 2002. St. Paul, Minnesota, 2002.

27 Niskanen WW. Letter to Roy E. Marden, Manager of Industry Affairs, Philup Morris Companies. 1991. Philip Morris. Bates No. http://www.pmdocs.com/ getallimg.asp?if=avpidx@DOCID = 2023585629/5630 [Accessed Oct 28, 2002].

28 Crane EH. Letter to Thomas C. Griscom, Executive Vice President for External Relations. 1995. R.J. Reynolds. Bates No. 512012069. http:// legacy.library.ucsf.edu/tid/myt40d00 [Accessed Oct 28, 2002].

29 Crane EH, Niskanen WA. Cato Institute 1996 Annual Report. 1996. Philip Morris. Bates No. 2073912779-2822. http://www.pmdocs.com/cgi-bin/ rsasearch.asp [Accessed Oct 30, 2002]

30 Kirkendall R. Interview with Theodore H. Tsoukalas. In, 2002.

31 Hurt R. Interview with Jennifer Ibrahim. In, 2003.

32 Anon. Spending the tobacco money: more bans, less help for smokers. Minneapolis Star-Tribune, 2001.

33 People's Voice Committee. Campaign Financial Report [for Period of 26 October 2001 to 6 December 2001]. Duluth: City Clerk's Office; 2001 December 6.

34 People's Voice Committee. Campaign Financial Report [for Period of 27 August 2001 to 25 October 2001]. Duluth: City Clerk's Office; 2001 October 26.

35 Anon. When it comes to MPAAT money, it's who you know. Minneapolis Star Tribune 18 November 2001.

36 Asch M. Interview with Jennifer Ibrahim. In, 2003.

37 Phelps D, Caulfield-Rybak D. Nonprofit group still pushing for smoking bans; MPAAT affirmed its priorities in a meeting that included resignations over possible conflicts of interest. Minneapolis Star-Tribune 21 May 2002.

38 Minnesota Partnership for Action Against Tobacco, Blue Cross Blue Shield of Minnesota, Minnesota Department of Health, Minnesota Smoke Free Coalition. Secondhand Smoke: Knowledge, Attitudes, and Behaviors of Minnesotans. In, 2000.

39 Hurt R. Richard Hurt: MPAAT doing a lot to reduce tobacco use in Minnesota. In: Minneapolis Star-Tribune; 2001.

40 Stawicki E. Hatch's tobacco ties questioned on eve of court fight. In. St Paul, Minnesota: MPR News, 2002.

41 Minnesota Ethical Practices Board. Report of receipts and expenditures for principal campaign committee for calendar year 1994. St Paul, MN: Minnesota Ethical Practices Board, 1994.

42 Minnesota Ethical Practices Board. Report of receipts and expenditures for principal campaign committee for calendar year 1998. St Paul, MN: Minnesota Ethical Practices Board, 1998.

43 Minnesota Statutes. In:, Attorney General.

44 Caulfield-Rybak D, Phelps D. Lawmakers to scrutinize anti-smoking group's activities. Minneapolis Star-Tribune; 22 January 2002.

45 Caulfield-Rybak D, Phelps D. Hatch: Group should give up smoking-ban campaigns. In: Minneapolis Star-Tribune; 2002.

46 The State of Minnesota, by Hubert H. Humphrey III, It's Attorney General, and Blue Cross and Blue Shield of Minnesota, Plantiffs, Vs. Philip Morris Incorporated, R.J. Reynolds Tobacco Company, Brown \& Williamson Tobacco Corporation, B.A.T. Industries P.L.C., British-American Tobacco Company Limited, Bat (U.K. \& Export) Limited, Lorillard Tobacco Company, the American Tobacco Company, Liggett Group, Inc., the Council for Tobacco Research - U.S.A., Inc., and the Tobacco Institute, Inc., Defendents: Consent Decree. In: State of Minnesota District Court, County of Ramsey, Second Judicial District, 1998

47 Hurt R. Interview with Theodore Tsoukalas. In, 2002

48 Caulfield-Rybak D, Burcum J. Hatch: Give MPAAT's money to 'U, Department of Health. Minneapolis Star-Tribune; 19 April 2002.

49 Scheck T. Tensions rise between Anti-Tobacco Group, Hatch. In: Minnesota Public Radio Online, 2002.

50 Grant AH. Lung cancer survivors, two former governors support Hatch's proposal. Minneapolis- Star Tribune; 2002.

51 Ragsdale J. Fund-raiser has foes fuming: tobacco lobbyists among sponsors of Carlson event. St Paul Pioneer Press 4 October 1994; Sect. 1C, 4C.

52 Association for Nonsmokers Rights. Update on Tobacco Bills in the Minnesota House and Senate: March 1994-May 1994. St. Paul, MN: ANSR, 1994.

53 Freedberg L. Tobacco's new clout in Washington. In. San Francisco, CA, San Francisco Chronicle; 2001

54 Tobacco Institute. Tobacco Institute. 1994 Proposed Budget. December 11 1993. Lorillard Tobacco Co. Bates No. 91082882/2938. http:// www.lorillarddocs.com/getimg. asp?pgno $=0$ \&start $=0$ \& if $=$ avlid $\times$ \&bool $=$ Did\%3A\%2091082882\&docid = 91082882/ 2938\&docnum $=1$ \&summary $=0 \&$ sel $1=[$ Accessed April 1, 2002]

55 Mowery A. Press release: MPAAT responds to attorney general's attacks. In. St Paul; 2002.

56 Phelps D. Tobacco money feud goes to court; at issue is MPAAT's antismoking mission, attorney general says. Minneapolis Star-Tribune 17 May 2002.

57 Howe P. American Cancer Society defends embattled anti-smoking fund. In. St Paul: Pioneer Press; 2002. 
58 Pattison K. Minnesota: lawyers spar over MPAAT's activities. In: St Paul Pioneer Press; 2002.

59 Phelps D. Dispute over anti-tobacco group heads back to the courthouse. Minneapolis Star-Tribune; 2002.

60 The State of Minnesota, by Hubert H. Humphrey III, It's Attorney General, and Blue Cross and Blue Shield of Minnesota, Plantiffs, Vs. Philip Morris Incorporated, R.J. Reynolds Tobacco Company, Brown \& Williamson Tobacco Corporation, B.A.T. Industries P.L.C., British-American Tobacco Company Limited, Bat (U.K. \& Export) Limited, Lorillard Tobacco Company, the American Tobacco Company, Liggett Group, Inc., the Council for Tobacco Research - U.S.A., Inc., and the Tobacco Institute, Inc., Defendents. Amicaus Brief of the Tobacco Control Resource Center. In: State of Minnesota District Court, County of Ramsey, Second Judicial District, 1994.

61 Siegel M, Carol J, Jordan J, et al. Preemption in tobacco control. Review of an emerging public health problem. JAMA 1997;278:858-63.

62 Heironimus J. Impact of workplace restrictions on consumption and incidence. January 22 1992. Philip Morris. Bates No. 2023914279/4284. http:// legacy.library.ucsf.edu/tid/rvv24e00 [Accessed Oct 23, 2002].

63 Mills K. Judge Orders MPAAT to form plan to help individual smokers quit. In: Star-Tribune. June 27, ed: Minneapolis Star-Tribune; 2002.

64 Phelps D. MPAAT must only help smokers quit; judge says smoking bans depart from its mission. Minneapolis Star-Tribune, 2002 June 28.

65 Phelps D. Judge asks some questions about antismoking group's strategy. In: Minneapolis Star-Tribune; 2002.

66 Ogelesby M, Mozingo R. National Cancer Institute/American Cancer Society - Project Assist. October 4 1991. RJ Reynolds. Bates No. TIMN0019101/ 9106. http://legacy.library.ucsf.edu/tid/zdj53d00 [Accessed Feb 5, 2004].

67 Minnesota Partnership for Action Against Tobacco (MPAAT). New comprehensive plans for MPAAT governance and individual smoking cessation activities. St Paul, MN: Minnesota Partnership for Action Against Tobacco, 2002

68 Our View: Judge's ruling allows state antitobacco unit to resume. In: Duluth News Tribune, March 5 ed. Duluth, MN, 2003.

69 The Associated Press. Judge Says He Won't Rule Again on Motion against MPAAT. In: Star Tribune. February 21 ed. Minneapolis: Star Tribune; 2003.

70 Marcotty J. Judge refuses to strip anti-tobacco group of funds. In. February 21 ed. Minneapolis: Star Tribune; 2003.

71 PRNews Wire. Ramsey County judge approves mpaat's plans to help smokers quit and restructure governance. In. February 26 ed. Star Tribune; 2003.

72 Caulfield-Rybak D, Burcum J. Tobaccy money targeted: hatch wants group's endowment stripped. In. April 20 ed. Minneapolis Star-Tribune; 2002.

73 Jacklin M. A Night lawmakers are expected to remember. Hartford Courant 2002 April 3.

74 Condon G. Smoking ban begins tomorrow; while some applaud, others fear businesses will suffer. Hartford Courant 2003 September 30:Sect. B1.

75 Manley M, Lynn W, Payne Epps R, et al. The American Stop Smoking Intervention Study for Cancer Prevention: an overview. Tobacco Control 1997;6(suppl 2):S5-11.

76 Tobacco Institute. The Tobacco Institute 900000 (1990) Budget. October 20 1990. Bates No. 640506690/6967. http://www.bw.aalatg.com/public.asp [Accessed January 20, 2002].
77 Tobacco Institute. The Tobacco Institute 1997 Budget, State Activities Division. December 9 1996. Bates No. TNW 0004485/4550. http:// www.tobaccoinstitute.com [Accessed April 10, 2001].

78 Tobacco Institute. The Tobacco Institute 990000 (1999) Proposed Budget August 27 1998. Bates No. 86599530/9649. http:// www.lorillarddocs.com/getallimg. asp?if = avlidx\&DOCID = 86599530/9649 [Accessed May 2, 2002].

79 Briant T. 1996 Funding Request for the Minnesota Wholesale Marketrs Association. August 29 1995. Legacy Tobacco Documents Library. Bates No. 568210319/0322. http://legacy.library.ucsf.edu/tid/frs90f00 [Accessed August 28, 2002]

80 Christensen N. Letter to Governor Carlson and Auditor Judy Dutcher Regarding Unlawful Use of Federal Taxpayer Dollars by Minnesota Department of Health and Violations of State Lobbyist Registration and Reporting Laws. October 18 1995. Legacy Tobacco Documents Library. Bates No. 2046641442/1445. http://legacy.library.ucsf.edu/tid/mnd04e00 [Accessed August 23, 2002].

81 Christensen N. Letter to Minnesota Ethical Practices Board Regarding Minnesota Department of Health Assist Project Groups. November 281995. Philip Morris. Bates No. 2046641431/1435. www.pmdocs.com [Accessed August 23, 2002]

82 Levin M. Legal Weapon; tobacco companies facing increasingly strong opposition, have Turned to Poen-Records laws to fight back; inundating state offices with requests for documents and, in some cases, using information from them to charge antismoking groups with improper use of public funds. Los Angeles Times 1996 April 21; Sect. D1.

83 Minnesota Partnership for Action Against Tobacco (MPAAT). About MPAAT: History. In: Minnesota Partnership for Action Against Tobacco (MPAAT), 2002.

84 Minnesota Partnership for Action Against Tobacco (MPAAT). What We Have Funded. In: Minnesota Partnership for Action Against Tobacco, 2002.

85 Brief of Amici Curiae for Case: Sharon Price and Michael Fruth, Individually and on Behalf of All Others Similarly Situated, Plaintiffs, V. Philip Morris Incorporated, Defendant. In: Third Judicial Circuit, Madison County, Illinois, 2003.

86 Wheat A. Attorneys general for sale? In: Multinational Monitor; 2001.

87 Traynor MP, Begay ME, Glantz SA. New tobacco industry strategy to prevent local tobacco control. JAMA 1993;270:479-86.

88 Mullan F. Don Quixote, Machiavelli, and Robin Hood: public health practice, past and present. Am J Public Health 2000;90:702-6.

89 Anon. Anti-smoking campaign files preemptive complaint against tobacco company. Delaware Corporate Litigation Reporter 2002;16(13):10.

90 Vose KK. American Legacy Foundation condemns tobacco company's unwarranted attack on Truth campaign. In: January $22 \mathrm{ed}$. American Legacy Foundation, 2002.

91 National Association of Attorneys General. Multistate Settlement with the Tobacco Industry. In: National Association of Attorneys General, 1998.

92 Anon. Breach non-signatory adoption public statements. Delaware Law Weekly 2003;6(7):d8

93 American Legacy Foundation, a Delaware Non-Profit Corporation, Plaintiff, V. Lorillard Tobacco Company, a Delaware Corporation, Defendant. Memorandum Opinion for Summary Judgement In: Court of the Chancery of the State of Delaware in and for New Castle County, 2003. 